\title{
Foreign Direct Investment and the SME Sector
}

\author{
Piers Thompson \\ Nottingham Business School, Nottingham Trent University, $8^{\text {th }}$ Floor Newton Building, \\ Burton Street, Nottingham, NG1 4BU. \\ piers.thompson@ntu.ac.uk
}

Wenyu Zang

Nottingham Business School, Nottingham Trent University, $8^{\text {th }}$ Floor Newton Building, Burton Street, Nottingham, NG1 4BU.

March 2015

This paper has been published in the: International Journal of Entrepreneurial Behavior and Research: http://dx.doi.org/10.1108/IJEBR-12-2013-0218

Please cite as following:

Thompson, P. and Wang, Z. (2015), "Foreign Direct Investment and the SME Sector", International Journal of Entrepreneurial Behavior and Research, Vol. 21 No. 1, pp. 50-75. doi: 10.1108/IJEBR-12-2013-0218 


\section{Foreign Direct Investment and the SME Sector}

\section{Structured Abstract:}

\section{Purpose}

Although foreign direct investment (FDI) and entrepreneurship are potential routes to recovery (Girma and Wakelin, 2001; Lyon et al., 2002), existing literature is divided on the relationship between the two. This study examines the influence of foreign investment on the local SME sector after the 2008 financial crisis.

\section{Design/methodologylapproach}

Local authority district data from Great Britain is used to examine the influence of foreign firm employment on the size of the local SME sector as a proportion of all firms, and foreign firm influence on firm births in the locality. In order to control for local geographical, infrastructural, and economic conditions regression analysis is used to examine the relationship between foreign business employment and indigenous business activities.

\section{Findings}

The potential for technological spillovers and spinout activities appears to dominate with firm birth rates higher where there is greater foreign firm employment. However, there is also evidence of crowding out in relation to the existing SME sector, which is found to be reduced in size where foreign influence through employment is greater.

\section{Research Implications}


The results here indicating a complementarity relationship between foreign influence on employment and firm births is important for policy makers looking to revive struggling local economies. However, the relevant support needs to be in place to maximise the benefit from the supply of new entrepreneurs generated.

\section{Originality/value}

Unlike many other studies the relationship between the SME sector, firm births and foreign influence is considered at a local level and where economic conditions are more uncertain and economic recovery is less taken for granted. A better understanding of the relationship allows more appropriate policy to be developed in order to aid local economies to recover.

Keywords: Foreign Direct Investment; Economic Resilience; New Firm Creation

\section{Article Classification: Research Paper}

\section{Introduction}

Whether countries are developed, emerging, or less developed often there is a considerable allure to attracting foreign direct investment (FDI) to a local or regional economy as this has the potential to create jobs and provide access to new technologies (Acs et al., 2007a). In addition to the direct influence on employment there are also potential secondary beneficial effects on job creation, or protection, through local businesses acting as suppliers to the foreign business (Javorcik, 2004) and local businesses and future start-ups gaining access to world leading technology (Acs et al., 2007b). However, FDI has been criticised as footloose (Görg and Strobl, 2003) and seeking locations with the lowest labour costs regardless of the source of this advantage (Bellak et 
al., 2008). Thus, FDI may not embed itself within the local economies, meaning that few local businesses benefit from supply contracts (Phelps et al., 2003; Simmie and Martin, 2010). Workers in such foreign affiliates would have less opportunity to display autonomy and intuition, distancing the local workforce from business ownership and entrepreneurship making it appear less feasible (Storey, 1994; Mueller, 2006). Further, competition from foreign affiliates for customers and inputs may weaken the existing small and medium sized enterprise (SME) sector (De Backer and Sleuwaegen, 2003).

In order to generate a thriving local economy it has been argued that an enterprise culture is beneficial, leading to a strong embedded presence from small and medium sized enterprises (SMEs) (Lyon et al., 2002). Thus, it is unclear whether FDI on average is beneficial in terms of generating the conditions where an enterprise culture can thrive. Further, in the period of greater economic uncertainty present in the aftermath of the Financial Crisis, the presence and nature of the links between foreign affiliates and indigenous SMEs could be a key factor in the ability of local economies to withstand (Simmie and Martin, 2010) and adapt to new conditions in order to recover (Hudson, 2010) from the economic shocks that have reached almost all parts of the global economic system and destabilised the previous economic hierarchy (Rae et al., 2012). Both of these attributes are linked to the concept of economic resilience (Christopherson et al., 2010). This means the relationship between FDI and local enterprise has important implications for local development policy. Although a number of studies of this relationship have been conducted at the national level and less frequently the regional level, studies such as Figlio and Blonigen (2000) and $\mathrm{Hu}(2007)$ have indicated that even studying the impact of FDI at the regional level hides the true extent of foreign firm's influence at the local level given the relatively immobile labour force in many European economies (Decressin and Fatás, 1995; McCormick, 1997). The shift from regional to localised development planning in the UK with the demise of regional development agencies (RDAs) and their replacement with local 
enterprise partnerships (LEPs) (HM Government, 2010a; 2010b; Crowe, 2011; Rossiter and Price, 2013), further raises the importance of understanding the links between these two planks of local economic development and resilience.

This paper seeks to establish which of these outcomes dominates in relation to the current economic crisis. In order to measure the impact of FDI on the local labour force, foreign influence is measured as the percentage of employment accounted for by foreign businesses. The relationship between this measure of foreign influence and measures of the size of the SME sector and firm births are examined. In order to control for other local factors that may influence the number of SMEs within the economy, and new businesses created, a regression approach is utilised.

The remainder of the paper is structured as follows. The literature associated with FDI, and in particular its influence on the local economy, are examined in the next section. The third section outlines the data and methods of analysis that are utilised within the study. The results of the analysis considering the size of the SME sector, firm births, and the influence from foreign ownership are outlined in section 4. Section 5 discusses these results and draws policy conclusions from the analysis undertaken.

\section{Foreign Direct Investment and Entrepreneurship}

2.1 The local and regional development context of the UK

A majority of studies considering the links between the presence of foreign firms and local enterprise performance has been undertaken at the national level. A small number of studies have considered regional FDI patterns (Hill and Munday, 1991; Wren and Jones, 2011; Dimitropoulou et al., 2013). However, Figlio and Blonigen (2000) and Hu (2007) 
suggest that the influence of foreign firm presence upon local firms and entrepreneurs may vary considerably within regions. The coalition government elected in 2010 has also moved the emphasis of development policy from the regional scale to a smaller more localised scale. This is embodied in the Localism Bill (HM Government, 2010a; Crowe, 2011) and Local Growth White Paper (HM Government, 2010b).

As part of this the 12 regional development agencies (RDAs) previously responsible for development policy in the regions have been replaced by 39 local enterprise partnerships (LEPs) with responsibility for policy across much smaller (in some cases overlapping) areas (Pugalis and Bentley, 2013; Rossiter and Price, 2013). It could be argued that this is in response to the problems of RDAs covering areas which do not correspond to labour markets and with cities within regions attracting quite different types of FDI (Almond et al., forthcoming). Maskell and Malmberg (1999) also note that the transfer of tacit knowledge is much easier at the local level, making analysis of sources of this knowledge such as FDI at smaller spatial scales more appropriate. Given the changing responsibility of economic development and the role that FDI plays in this (Almond et al., forthcoming) there is a need to understand the influence of foreign firms upon the local SME sector in times of economic uncertainty in order to develop appropriate support and policies.

The importance of this relationship is also been highlighted by the work on economic resilience where the adaptability of a local or regional economy is particularly important in fast changing conditions (Pike et al., 2010). This reflects as acknowledgement that past success is no guarantee of future economic growth and areas must be able to move to new development paths to ensure long run success (Christopherson et al., 2010; Martin, 2012). The flexibility of the SME sector and in particular the adaptability provided by firm births are seen as being a key part of this (Lyon et al., 2002). Clearly therefore it is important regardless of whether FDI provides immediate direct economic benefits or not that any 
positive or negative impact on the domestic SME sector is understood. Foreign influence could indirectly boost or limit local economic resilience through its influence of the local SME sector and relevant policies to aid recovery in the advent of an economic shock would need to take this into account.

\subsection{Foreign Direct Investment and Local Entrepreneurship}

Studies have suggested that there are two overriding effects of FDI on domestic enterprise and entrepreneurial activities, the competition effect and the demand effect (Barbosa and Eiriz, 2009). The competition effect refers to the negative impact that foreign affiliates have upon domestic businesses by increasing the competition for customers and factors of production, specifically labour (De Backer and Sleuwaegen, 2003). The demand effect reflects the additional business opportunities that FDI creates both directly through its demand for intermediate products and indirectly through the changes in production and managerial processes (Rodríguez-Clare, 1996; Markusen and Venables, 1999).

Occupational choice models normally assume that the propensity to engage with entrepreneurial activities is positively influenced by an individual's natural entrepreneurial/managerial abilities (Lucas, 1978; Oi, 1983), and negatively associated with their risk aversion (Kihlstrom and Laffont, 1979). The most able entrepreneurs would normally be drawn into starting their own businesses. The competition effect of FDI has two negative impacts on enterprise. First, it increases competition for custom, which reduces the relative profitability of entrepreneurial activities compared to the wages from working for others (Grossman, 1984). To avoid competition from foreign firms both existing SMEs and latent entrepreneurs contemplating entry may be forced into less profitable and lessinnovative niches ignored by foreign multinationals (Cantwell, 1989; Hanson, 2001). 
The second negative effect concerns foreign firms' higher productivity levels associated with their more advanced technology, which enables them to pay higher wages and skim the most able workers (Grossman, 1984; Girma et al., 2001; Martins, 2011). The overall impact is that not only is domestic entrepreneurial activity reduced, but the average ability of entrepreneurs also falls as the most able workers/entrepreneurs take positions within foreign affiliates (De Backer and Sleuwaegen, 2003). Further reducing experience within small businesses, Moy and Lee (2002) find that Hong Kong graduates view careers with multinational corporations as more attractive than with SMEs due to their perceived job security and long-term career prospects. SMEs also lose out as foreign firms push up labour costs and hinder their attraction of skilled and qualified workers (Spencer, 2008). Thus, the competition effect may reduce both the size of the existing SME sector and discourage high quality latent entrepreneurs from creating new ventures.

Other studies have suggested that the relationship between FDI and local entrepreneurship may be positive, especially in the long run (Görg and Strobl, 2001). A positive long run relationship reflects the potential for knowledge spillovers associated with geographical proximity (Girma et al., 2001; Foray, 2006). Studies such as Buckley et al. (2007) note the need therefore to examine the influence of FDI at lower geographical levels. This leads to the development of clusters of related industries seeking to take advantage of the benefits that collocation has in terms of knowledge creation (Audrestch and Feldman, 1996; Audretsch and Stephan, 1996). The strength of such positive spillovers, however, is disputed (Driffield et al., 2010).

Technical and managerial knowledge boosting production or quality may also be transmitted to domestic firms when employees move to existing SMEs or to start their own businesses (Caves, 1996; Fu, 2012). Benefits will be larger if experienced in areas outside the domestic firm's core competencies, as long as the firm is willing to adopt and adapt to 
this new knowledge (Song et al., 2003; Meyer, 2004). This experience working for foreign firms also enables latent entrepreneurs to develop their professional networks, which will be vital to the success of their own future ventures (O'Malley and O'Gorman, 2001; Bandelj, 2008). In Ireland O'Malley and O'Gorman (2001) found a majority of Irish software entrepreneurs had previously worked in foreign firms. This route to entrepreneurship may be particularly important in economic downturns where staff are laid off from foreign employers and seek to create their own enterprises (Feldman et al., 2005; Carlsson, 2006). This relationship is indirect, with the skills and knowledge of the workforce including managerial skills, being released into the SME sector through new firm births.

The entry of foreign firms can generate new entrepreneurial opportunities that weren't present before as the foreign firms introduce new goods to the market, and raise customer awareness of these goods (O'Malley and O'Gorman, 2001). Local imitators avoid development costs (Aldrich and Ruef, 2006) and are unencumbered by 'liabilities of foreignness' (Zaheer, 1995). Other opportunities include supplying locally tailored complements to the foreign firms' goods (Pitelis and Teece, 2010).

Foreign firms will also have demand for upstream and downstream goods and services, all of which can be fulfilled by domestic entrepreneurs (Rodríguez-Clare, 1996; Markusen and Venables, 1999; Javorcik, 2004). Entrepreneurial activities that create new ventures to supply foreign affiliates may be particularly valuable to weaker local economies because, as Barbosa and Eiriz (2009) argue, such activities class as international entrepreneurship given the international nature of their customers. Trading relationships between domestic enterprises and foreign affiliates are also important in increasing the probability of knowledge and technology spillovers (Görg and Strobl, 2005; Haskel et al., 2007; Blalock and Gertler, 2008; Keller and Yeaple, 2009; Blalock and Simon, 2009). 
Empirically, using data from Belgium (De Backer and Sleuwaegen, 2003) and Ireland (Barrios et al., 2005) it is found that FDI does crowd out domestic enterprise with entry rates falling when foreign entry is higher. Competition via FDI has a larger negative effect than imports, suggesting that the second potential influence identified by Grossman (1984), that of skimming labour, is also present. De Backer and Sleuwaegen (2003), however, do also find some evidence for the longer-run positive relationship between FDI and domestic entrepreneurship. Interestingly Barbosa and Eiriz (2009) paint a different picture using data from Portugal. Their findings suggest that whilst there is weak evidence of an initial positive effect this is quickly displaced by a strong negative relationship between net entry and foreign presence in an industry. Kim and Li (2014) find a positive relationship between new business registration and inward investment, but this is moderated by contextual factors. The presence of stronger institutions supporting private enterprise, higher general human capital and greater political stability all reduce the strength of this relationship. In more developed countries such as the UK, which have stronger institutions, it would therefore be expected that local enterprise would gain less from the presence of FDI.

Further casting doubts on the benefits of FDI for the SME sector, Girma et al. (2001) find the presence of foreign firms on average has no impact on productivity in UK firms. Görg and Strobl's (2001) meta-analysis of spillovers also indicates that some studies' results suggesting a positive effect on local productivity may reflect FDI being drawn into high productivity sectors as cross sectional analysis tends to find a stronger relationship than that found in panel data analysis where industry differences can be controlled for.

In terms of regional analysis, Haskel et al. (2007) although finding spillovers from foreign presence in the same industry boosting productivity, find no productivity increase from foreign presence in the same region. This supports the need for trading connections to be made to receive benefits (Görg and Strobl, 2005). A geographical influence is still 
potentially important as Girma and Wakelin (2001), concentrating on the UK electronics industry, found the productivity benefits received from spillovers varied between regions depending on the scale of Japanese electronics FDI undertaken.

The existing theory gives no clear indication of the overall expected effects of foreign presence on the size of the domestic SME sector and firm births. Falling advantages of spillovers and new demand from foreign influence may limit benefits in countries such as the UK where favourable institutional conditions for new venture creation are already present (Kim and Li, 2014). Studies of productivity spillovers in the UK tend to find little evidence (Girma et al., 2001), or where positive results are found, they are restricted to firms in the same industry (Haskel et al., 2007). Given the limited positive demand effect to offset the negative competition effect, this therefore suggests a negative relationship between foreign influence and the local SME sector might be expected as outlined in the hypothesis below.

H1a: Where foreign influence is higher the SME sector will be smaller.

With regard to firm births specifically, previous studies have not considered periods of economic uncertainty as is the case here, where foreign firms reducing employment may release latent entrepreneurial talent into the economy (Feldman et al., 2005). However, studies considering countries at similar levels of development to the UK, such as Ireland (Barrios et al., 2005) and Belgium (De Backer and Sleuwaegen, 2003) tend to find more evidence of a negative crowding out effect.

H1b: Where foreign influence is higher the business start-up rate will be lower. 
Where links are formed local actors have to be able to not just access, but absorb and transform knowledge (Meyer and Sinani, 2009). This makes the adsorptive capacity of local firms an important factor in this link (Cohen and Levinthal, 1990). Studies such as Girma et al. (2001) and Liu et al. (2000) indicate the key determinant of productivity spillovers in the UK manufacturing sector is the technological capacity of the domestic firms. Too large a technology gap and transfer is hard to achieve. Meyer and Sinani's (2009) meta-analysis suggests that a $U$ shaped relationship between positive spillovers and level of development as captured by income, institutions or human capital. However, in more advanced economies, such as the UK, most foreign investments do not incorporate a R\&D function (Bishop and Wiseman, 1999), which limits access to cutting edge knowledge for indigenous entrepreneurs.

As this study is considering the transfer of knowledge not only from foreign affiliates to existing firms, but also to new firms, it is the absorptive capacity of the workforce as a whole which would be expected to be key. In this respect the study is following a similar approach to studies such as Gu and Lundvall (2006), Fu (2008) and Mahroum et al. (2008) in considering the absorptive capacity at the local or regional level. This view can be combined with the knowledge spillover theory of entrepreneurship (Audretsch and Lehmann, 2005) to understand the role of human capital in the relationship between foreign influence and the local SME sector and firm births. This suggests uncommercialised knowledge in existing firms and institutions, such as universities, provides a source of business opportunities, which are realised by entrepreneurs through new venture creation. The local workforce's ability to absorb knowledge from foreign firms for any positive link from foreign presence to entrepreneurial activity is therefore extremely important. As with spillovers in general, for more advanced economies it is expected that greater human capital will have a positive mediating effect (Meyer and Sinani, 2009). However, the form of human capital in question influences the mechanism through which human capital operates in boosting 
regional development in general. For example, Florida et al. (2008) find that measures of human capital associated with the creative classes is linked to productivity increases, whilst more general human capital captured by education qualifications has the strongest association with regional income. In terms of a region accessing knowledge from foreign firms Roper and Love (2006) suggest that tertiary education whilst not directly linked to firm innovations plays an indirect role through increasing regional absorptive capacity. Other studies understandably find links between employment in R\&D positions and innovative outputs (Abreu et al., 2008; Huggins et al., 2014). Studies of entrepreneurship have indicated that both industry experience (Colombo and Grilli, 2005; Delmar and Shane, 2006; Dahl and Reichstein, 2007) and formal qualifications (Davidsson and Honig, 2003; van der Sluis and van Praag, 2008) are positively associated with new venture creation and their performance post start-up. However, as with regional development, the impact of human capital from different sources may be distinct. Ucbasaran et al. (2008) find that entrepreneurship-specific human capital such as managerial capabilities play the greatest role in opportunity identification and pursuit rather than more general forms as captured by educational qualifications. Robinson and Sexton (1994), however, find that formal education is more closely related to self-employment than more general employment experience. This leads to the following hypotheses:

H2a: Greater human capital in local areas will positively moderate the relationship between foreign influence and the size of the SME sector.

H2b: Greater human capital in local areas will positively moderate the relationship between foreign influence and the start-up rate present.

2.4 Industrial structure, foreign influence and entrepreneurship 
Although the demand effect and knowledge spillovers suggest local economic benefits of local SMEs engaging with foreign affiliates the use of local supply chains is limited with greater reliance on established global supply chains (Phelps, 1993). Crone and Watts (2000) and Crone (2002) suggest that multinationals in the UK, source less than 2 percent of their inputs from local SMEs. Nevertheless, FDI in the manufacturing sector will provide the greatest opportunities to supply inputs (Ben Hamida and Gugler, 2009). In addition, a smaller proportion of technology may be embedded in firm specific human capital and tacit knowledge than is the case in the service sectors (Blomström and Kokko, 2002). Thus, local SME sectors where manufacturing plays a greater role may gain more from foreign influence in the local economy.

H3a: Where manufacturing makes up a larger proportion of employment this will positively moderate the relationship between foreign influence and the size of the SME sector.

The UK manufacturing sector suffered one of the greatest declines in the aftermath of the financial crisis (Plunkett and Pessoa, 2013). Where larger employers close down this may release latent entrepreneurs to generate the next generation of start-ups and actually be the seeds of a new cluster (Feldman et al., 2005; Carlsson, 2006). Thus, after the economic crisis the potential to supply foreign affiliates could potentially mean where manufacturing employment is higher there will be more start-ups and a larger foreign presence will interact with this to raise employment further. These positive influences may be tempered if as found in some studies, experience in manufacturing employment is less appropriate for the challenges faced in new firm creation within an SME sector dominated by service firms (Carree et al., 2002; Fotopoulos, 2014).

H3b: Where manufacturing makes up a larger proportion of employment this will positively moderate the relationship between foreign influence and firms births. 
Obviously the other sector which was affected strongly by the financial crisis was the financial services sector, which plays a prominent role in the UK economy, although not uniformly across localities (Pandit et al., 2002). Foreign financial services firms may be drawn to the UK to utilise the existing skilled workforce of the UK. For example, nonmanufacturing FDI in the South East of England is positively associated with the presence of clusters (Fallon and Cook, 2014). In Switzerland, Ben Hamida and Gugler (2009) suggest that in more efficient industries such as the Swiss banking industry reverse spillovers may occur as foreign firms look to learn from world leaders. This makes the skimming of labour, outlined previously, perhaps more of a factor harming local enterprise.

H3c: Where financial services make up a larger proportion of employment this will negatively moderate the relationship between foreign influence and the size of the SME sector.

H3d: Where financial services make up a larger proportion of employment this will negatively moderate the relationship between foreign influence and firms births.

\section{Data and Methods}

\subsection{Measuring Foreign Influence}

Although studies of FDI have examined the economic impact at a regional level, this can often hide the impact that these multinational firms have on localised labour markets (Figlio and Blonigen, 2000). With this in mind this study examines the impact that FDI has on local enterprise at the local authority district level of spatial disaggregation. In total there are 380 localities at the local authority district level in Great Britain. These subdivisions are imperfect in being based on administrative responsibility rather than any economic or 
community based grouping, but provide access to a wider array of secondary data than alternative spatial divisions. Three local authority districts are excluded from the main analysis due to missing data, Cornwall, the Isles of Scilly, and the City of London.

Given the importance of FDI to economies it is relatively surprising that so little data is available in relation to the extent and location of foreign investment within Great Britain. No official data is available on the location of capital invested within Great Britain (Billington, 1999), although single one off estimates at the regional level have been produced (Hill and Munday, 1991). Alternatively the number of projects has been used instead (Wren and Jones, 2011; Dimitropoulou et al., 2013). These regional FDI figures should be treated with a degree of caution according to scholars such as Stone and Peck (1996) and Munday et al. (2009). When considering the influence of foreign owned businesses on the local labour force, measures of capital invested, or worse projects, may not necessarily reflect the true impact, as more capital intensive industries may have a less direct influence on the enterprise culture (Barbosa and Eiriz, 2009). In order to overcome the deficiencies of FDI data, we employ the proportion of the workforce that can be attributed to working in foreign owned firms as the degree of foreign influence in the local economy. This measure has the added advantage of more directly relating to the influence on the workforce and therefore entrepreneurial activities as outlined in section 2 above. This measure is provided by the Office for National Statistics's (ONS) 'Foreign Ownership of Businesses in the United Kingdom Analysis' (ONS, 2010). This is based on the Value Added Tax (VAT) and Pay As You Earn (PAYE) registered units included within the Inter-Departmental Business Register (IDBR), so will ignore the smallest more informal businesses. It is impossible to determine the ownership of some businesses within the sample, but there is no reason to assume that there will be any systematic differences across localities with regard to these businesses with unattributable ownership. The data, produced on a one off basis, relates to 2010 and therefore the relationship between this foreign influence and enterprise culture can be 
examined by considering the latest data on the local SME sector and firm births. Whilst many studies utilise the flow of FDI into an economy, Kim and Li (2014) find that similar results are produced where lagged FDI flows are replaced by stock of FDI, which is more akin to our measure here.

Given Buckley et al.'s (2007) findings that the relationship between foreign influence and spillovers affecting local enterprises' productivity is non-linear a quadratic term is used in some specifications to allow for a similar relationship existing between foreign presence and entrepreneurial activity. The variables are centred around their means to reduce the potential problems associated with collinearity from the inclusion of quadratic terms (Cohen et al., 2003).

\subsection{SME and Entrepreneurial Activity}

The size of the SME sector is captured as the number of SMEs (firms with less than 250 employees) as a percentage of the business stock. The data is drawn from the ONS UK Business: Activity, Size and Location publication for 2011. To provide information on the renewal of the SME sector in periods of uncertainty, the number of new businesses created in 2011 are examined using data from the ONS Business Demography publication. To account for the differing sizes of local economies firm births are scaled by the existing business stock at the beginning of 2011. Thus, firm births are measured as a proportion of the existing business stock.

\subsection{Regression Estimation Approach}

In order to account for a number of other influences on the small business sector a multiple regression approach is adopted. Other variables in the regressions attempt to encapsulate: 
industrial and urban structure; the labour force structure; access to transport infrastructure; and local economic conditions. Table A1 in the appendix provides a summary of the variables used. Although, the Variance Inflation Factors (VIFs) suggest that problems with collinearity are within acceptable limits when all variables are included (the maximum VIF with all variables is $\mathbf{5 . 1 4}$ for Managerial and Professional positions variable), the relationship between the human capital and industry sector variables associated with hypotheses $\mathrm{H} 2 \mathrm{a}$, $H 2 b, H 3 a, H 3 b, H 3 c$, and $H 3 d$ makes it prudent to include these in separate regression estimations. This means for the size of the SME sector three models are estimated incorporating: NVQ level 4 or greater qualifications (Model A1); managerial, professional and associate professional positions (Model A2); employment in manufacturing and financial services (Model A3). Equivalent models are estimated for firm births are estimated (Models B1, B2 and B3). The maximum VIF is then 3.32 for the median wage rate in the regressions including Managerial and Professional positions (Model A2). The rationale for including each variable with the regression is explained in detail below along with details of the specific measures utilised to capture them.

\subsection{Industrial and urban structure}

Although more rural areas are often perceived to have a stronger tradition of business ownership (Stathopoulou et al., 2004), they also lack the potential: knowledge flow (Vernon, 1960), access to thick specialised labour markets (Baker et al., 2005), and knowledge spillover (Delgado et al., 2010), benefits associated with an agglomeration. This can mean that whilst stable market conditions and greater embeddedness aid SMEs their long term competitiveness may be eroded (Anderson et al., 2010). For the sake of consistency, a simple measure based on population density (population per hectare) is utilised based on data from the midyear population estimates. Controls are included for the proportion of employment in the financial services and manufacturing sectors using data from the Annual 
Population Survey (APS). These industries are chosen as being vulnerable to the financial crisis and interacting with foreign influence.

\subsection{Labour Force Structure}

It is normally assumed that a degree of experience is required before starting a business (Baum and Silverman, 2004; Collins et al., 2004). However, starting a business requires a considerable investment, in terms of financial capital, time and effort which requires a period of time to achieve a return (Lévesque and Minniti, 2006; Kim, 2007). As Harding (2007) finds that the entrepreneurial propensity is highest for the 35 to 44 year old age group in the UK, the proportion of the population in this age group is included in the regression. The proportion of the population holding university level qualifications (equivalent to National Vocational Qualification (NVQ) level 4 or higher) is also included as a more formalised measure of human capital. To capture work related experience the proportion of employment in managerial, professional and associate professional occupations is included. Both measures are utilised given previous studies findings that general and more specific human capital can play differing roles in both regional development (Florida et al., 2008; Abreu et al., 2008) and specifically new venture creation (Ucbasaran et al., 2008).

\subsection{Transport Infrastructure}

As globalisation increases, the flow of goods and people between areas provides access to both markets and new ideas (Bathelt et al., 2004; Florida, 2002). To capture the domestic connections the gross number of rail journeys per head of population (Department of Transport/Office of Rail Regulation) is included. Dummies representing close proximity (25 miles) to a major airport (serving at least 4 million passengers in 2008) and primary 
maritime port (handling at least one million passengers or 25 million tonnes of freight in 2002 as measured by the Department for Transport) are included to represent international links.

\subsection{Local Economic Conditions}

Local economic conditions can have a dual impact on the SME sector. More affluent areas are likely to draw in entrepreneurs through a prosperity pull as they provide greater demand for goods and services, increasing their perceived profitability (Storey and Johnson, 1987; Blanchflower and Oswald, 1990). However, those out of work have been found to be significantly more likely to start a business as a refuge from unemployment (Evans and Leighton, 1989), described as being influenced by a recession push (Taylor, 1996). In order to capture the prosperity pull effect the median income for an area is included in the regressions (Annual Survey of Hours and Earnings). To avoid collinearity problems, the change in unemployment rate in 2010 compared to the average for the preceding five years is utilised to capture the extent that there are additional unemployed individuals who may be pushed into starting a business.

\subsection{Interactions between Foreign Influence, Sector and Human Capital}

As outlined in section 2 there is potential for interaction between the foreign influence variable and the local industry structure or human capital present in the locality. To test for the relationships outlined in hypotheses 2 to 3 , the regressions are run with interactions between foreign influence and: employment in financial services; employment in manufacturing; the proportion of the population possessing NVQ level 4 qualifications; and the proportion of workforce employed in managerial and professional positions. As noted in sub-section 3.3 above, issues of collinearity mean separate regressions must be run for the 
industry sector dummies and each measure of human capital. Within each regression model we allow interactions between the relevant industry sector or human capital controls.

\section{Results}

\subsection{Foreign Employment Influence and the Entrepreneurship Index}

Before examining entrepreneurial activity as manifested by the size of the SME sector and new firm births we compare the pattern of foreign employment influence and an index of local entrepreneurship potential inspired by Storey (1982). This index is intended to capture those areas which have a high abundance of those factors associated with entrepreneurial activity. Storey sets out six factors associated with areas capable of generating high levels of entrepreneurship: size of incubator firm, occupational experience, education, access to capital, entry into industry, and markets. The assumption being that the potential for entrepreneurial activity will be greater where localities' populations have: relevant small firm and managerial experience; higher human capital; access to capital via greater collateral; and face a smaller presence of industries with high costs of entry; and prosperous local markets to serve. One or more indicators are used to represent each of these factors as outlined in Table A2. The factors are given an equal weighting to generate the overall index. The factors are measured in an ordinal fashion based on the localities' rankings rather than their absolute values. The locality with the value most strongly associated with entrepreneurship for each variable is given a score of 378 , the locality with the value least associated with entrepreneurship a score of 1 (Cornwall is retained for this initial analysis with only the City of London and the Isles of Scilly excluded). 
Table 1 outlines the top and bottom 10 localities according to the entrepreneurship index in Britain. Regionally there is evidence that localities from the South East dominate the top of the table, but Ruschliffe from the East Midlands is also present. The localities with less entrepreneurial potential according to the index are frequently drawn from the East Midlands. The level of foreign influence varies considerably between both the top and bottom regions and so there is no obvious link at the extremes of the scales. However, the Spearman rank correlation coefficient does suggest a negative relationship, so that those areas with higher foreign influence tend to have lower entrepreneurship index ranks. If the entrepreneurship index does accurately reflect a locality's entrepreneurial potential then these results are consistent with hypotheses $\mathrm{H} 1 \mathrm{a}$ and $\mathrm{H} 1 \mathrm{~b}$.

\subsection{Bivariate Correlations}

Moving to the analysis of foreign influence's impact on actual entrepreneurship as captured by the size of the SME sector and new firm births, Table 2 presents the correlation coefficients associated with the relationships between the independent variables and the measures of entrepreneurial activity. All of the independent variables are significantly correlated with at least one of the entrepreneurship measures. The simple correlations are consistent with the positive relationship found by a number of studies linking FDI and domestic firm births (Kim and Li, 2014). However, this could reflect a recession push if unemployment rates have been increased substantially where foreign firms have reduced demand and employment, forcing the unemployed to take temporary refuge in selfemployment (Bradbury, 1994). The overall impact on the SME sector, which is likely to be a longer term pattern is negative, consistent with heightened competition and crowding out dominating (Barbosa and Eiriz, 2009; De Backer and Sleuwaegen, 2003). 
Firm births are greater in richer localities with higher median wages pulling them in (Storey and Johnson, 1987; Blanchflower and Oswald, 1990), but where unemployment has increased more there is also evidence of individuals being pushed into entrepreneurship (Evans and Leighton, 1989). Financial services with their smaller scale appear to be more suited to generating new ventures with the firm birth rate higher, whilst where manufacturing accounts for more employment the large scale required potentially limits firm births. Both measures of human capital are positively linked to the firm birth rate. Firm births are positively associated with many factors associated with larger more dynamic markets such as rail connections, access to airports and ports and denser urban areas. However, many of these factors are negatively associated with the size of the SME sector. Larger dynamic markets may encourage new firm births, but the competition this generates limits the protected niches for SMEs to operate within (Anderson et al., 2010).

\subsection{Foreign Influence and SME Sector Size}

As is the case for all the regression results presented, the F-tests for the SME sector size regressions reject the null of joint insignificance at the 1 percent level (Table 3). The regressions explain between 45.7 percent and 46.1 percent of the variation in the size of the SME sector depending on the human capital and industry sector variables included. Consistent with hypothesis $\mathrm{H} 1 \mathrm{a}$ and previous national industry level studies (Barrios et al., 2005; Barbosa and Eiriz, 2009), the direct effect of foreign influence on the size of the SME sector is negative and significant at the 1 percent level (Models A1, A2 and A3).

\section{PLEASE INSERT TABLE 3 ABOUT HERE}

The quadratic terms for foreign influence are not significant in any of the equations, suggesting unlike Buckley et al.'s (2007) findings for productivity spillovers the relationship 
with SME sector size appears linear. In order to establish whether there is any benefit in accounting for interactions from human capital and industry structure with the relationship between foreign influence and the size of the SME sector, F-tests of the change in $R^{2}$ are used. Model A1 finds a significant nonlinear interaction between human capital as captured by the proportion of the population NVQ level 4 or above qualifications and foreign influence. Model A1 suggests that higher levels of human capital may positively influence the size of the SME sector with low or high levels of foreign influence. Overall though there is no support for hypothesis H2a.

A significant positive interaction is found between the proportion of employment in the manufacturing sector and foreign influence (Model A3). This is consistent with the positive moderation effect outlined in hypothesis $\mathrm{H} 3 \mathrm{a}$. The coefficients on the other independent variables are consistent with the relationships found for the simple correlations.

\subsection{Foreign Influence and Firm Births}

Approximately seven tenths of the variation in entrepreneurship rates across the local authority districts can be explained by the regressions (Table 4). The regressions indicate that after accounting for other influences there is still a positive relationship between the proportion of the labour force that is employed within foreign owned firms and new firm creation contradicting hypothesis $H 1 b$ and some prior national studies (Barrios et al., 2005). The quadratic foreign influence terms are not significant, indicating that this relationship is linear in nature. 
The F-tests of change in $R^{2}$ indicate that allowing for interactions between foreign influence and human capital significantly improves the fit of the model. This is the case when human capital is measured both by the more general human capital measure of NVQ level 4 or above (Model B1) and the more specific measure, managerial and professional experience (Model B2). Some evidence of a negative interaction between human capital and foreign influence is found regardless of which measure is used. NVQ level 4 qualifications and foreign influence have a negative interaction significant at the $5 \%$ level (Model B1), whilst managerial and professional positions a similar negative interaction is estimated although only significant at the $10 \%$ level (Model B2). This runs contrary to the expectations of a positive moderating effect of human capital on the relationship between foreign influence and firm births set out in hypothesis $\mathrm{H} 2 b$.

Regarding the moderating influence of industry sector, the interaction terms were found to significantly improve the $R^{2}$ in Model B3. Greater employment in the financial services sector is found to weaken the positive effect of foreign influence on firm births (hypothesis H3d). The opposite was expected where manufacturing employment is higher, but no support for hypothesis $H 3 \mathrm{c}$ was found.

\section{Discussion and Conclusions}

\subsection{Discussion of Results}

Studies have previously suggested that FDI has both positive and negative effects on domestic entrepreneurship, based around a competition and a demand effect. This study looked to examine the relationship at a local level rather than the national level that is often 
utilised and considered a period of economic uncertainty when the global economy has suffered a substantial adverse shock. Drawing on the concept of economic resilience, the study suggested that beyond the direct employment effect it is worth considering the impact that foreign business presence and its dominance of the labour market may have in a longer term perspective. Here it was suggested that the lack of embeddedness of foreign firms may lead to a weakening of local economic resilience. The greater competition from foreign firms for custom and inputs may negatively affect existing businesses, whilst limited trading and interactions between foreign firms and domestic SMEs reduce the potential for positive productivity spillovers (Girma et al., 2001). This may reduce the size of the SME sector (hypothesis H1a), which has the potential to provide flexibility and adaptability (Lyon et al., 2002), so that the local economy finds it harder to withstand and recover quickly from an external economic shock. Based on national studies of countries at similar stages of development to the UK, it was also expected that a negative effect would be found upon firm births from foreign influence (hypothesis $H 1 b$ ). However, as subsection 2.2 outlined, there was the potential that foreign businesses may also be a major source of potential new entrepreneurs, and such a shock may actually be the spark that helps to develop a more robust and larger local SME sector. The results presented above indicate relationships that are consistent with both of these patterns. Whilst the local SME sector tends to be smaller in those areas where foreign businesses account for a larger share of employment (hypothesis $\mathrm{H1a}$ ), there is also evidence for higher levels of new firm entry contradicting some previous studies and the expectations set out in subsection 2 (hypothesis H1b). This is suggestive of the foreign firms being a potential source of entrepreneurial talent and training in periods of economic uncertainty (Caves, 1996; Carlsson, 2006; Fu, 2012). These local areas where foreign influence is greater are therefore likely to have a larger share of new businesses that are potentially better placed to adapt and move the economy to a position to take advantage of the opportunities that a recovery will bring. 
Although some studies suggest that in order to benefit from knowledge spillovers from foreign businesses a higher level of local or regional absorptive capacity is important (Cohen and Levinthal, 1990; Liu et al., 2000; Roper and Love, 2006; Meyer and Sinani, 2009), the positive moderating effects of human capital on the relationship between foreign influence and both the size of the SME sector (hypothesis H2a) and firm births (hypothesis $\mathrm{H} 2 \mathrm{~b}$ ) was absent. Instead, a negative interaction is found contradicting hypotheses $\mathrm{H} 2 \mathrm{a}$ and $H 2 b$, which may reflect the alternative opportunities present for more highly experienced and qualified latent entrepreneurs (Moy and Lee, 2002). This means that there is a danger that new venture creation may be higher where foreign presence is greater, but these businesses may not necessarily be serving more specialised and technologically advanced needs given the lack of evidence that local absorptive capacity plays a role.

Some evidence was also found of an interaction between industry structure and foreign influence for firm births in particular. Given the opportunities to trade with and serve manufacturing foreign affiliates (Ben Hamida and Gugler, 2009) as well as access the latest technology (Blomström and Kokko, 2002) a positive interaction between foreign influence and the share of manufacturing employment was outlined in hypotheses $\mathrm{H} 3 \mathrm{a}$ and $\mathrm{H} 3 \mathrm{~b}$. Although a significant positive moderating effect was found for the size of manufacturing sector on the relationship between foreign influence and the size of the SME sector (hypothesis $\mathrm{H3a}$ ) the opposite was found when considering firm births (hypothesis H3b). It appears therefore that although foreign influence may aid the existing SME sector through the demand effect, it may be that experience in larger manufacturing firms does not provide the necessary conditions and encouragement for latent entrepreneurs and counters any positive demand effect when it comes to firm births (Fotopoulos, 2014). Similarly as predicted in hypothesis $\mathrm{H} 3 \mathrm{~d}$ the size of the financial services sector has a negative moderating effect on the relationship between foreign influence and new firm births as 
foreign firms skim skilled labour from this more efficient sector (Ben Hamida and Gugler, 2009).

\subsection{Policy Implications}

Although foreign influence may reduce the size of the SME sector as outlined above the resilience of a region may not be reduced. This is because the positive effect of foreign influence on new venture creation may enable a local economy to more quickly adapt in periods of economic uncertainty. Policy support needs to have two elements to it. First the institutions associated with aiding new venture creation need to be present and resourced to ensure that if economic shocks occur which leads to a release of potential entrepreneurs from foreign employers, these entrepreneurs are able to access the advice and support required to take their knowledge into the local economy. Linked to this the second element is that on-going policy support should be provided to those wishing to start businesses associated with foreign employers. Through this a greater number of higher value enterprises might be created rather than SMEs associated with necessary driven motives, which may have limited growth potential (Block and Wagner, 2010). Currently there is less evidence that this is taking place in the UK as no positive interaction with human capital measures was found contrary to hypotheses $\mathrm{H} 2 \mathrm{a}$ and $\mathrm{H} 2 \mathrm{~b}$. In fact, the opposite appeared to be the case suggesting that skimming of top talent may be occurring (Grossman, 1984; De Backer and Sleuwaegen, 2003). Where future studies might help is in differentiating between the types of business created (and exiting the market) to analyse these patterns in much more detail.

\subsection{Limitations and Future Work}


The examination of local economies limits the ability to differentiate foreign influence between the industries present and the motivations behind the investments. Where FDI is in the same industry as domestic firms it would be of value to understand the extent that the skimming of most naturally able workers influences domestic entrepreneurship as a whole, as in the occupational choice models (Grossman, 1984; De Backer and Sleuwaegen, 2003), or whether related sectors are those that suffer, and whether this is offset by positive spillovers in those industries mostly closely linked (Görg and Strobl, 2005; Blalock and Simon, 2009). Studies such as Dunning (1992) and Blonigen et al. (2007) identify different motivations for FDI which will influence the extent that the competition and demand effects will take place (Barbosa and Eiriz, 2009). Studies of individual or groups of areas, particularly where defined by local social and economic connections rather than administrative responsibility, would further help to understand the policies that should be established to attract the types of FDI that is complementary to domestic entrepreneurship.

Another aspect of the study that constrains the ability to draw conclusions in relation to the impact of foreign influence on local economies is the measures of foreign influence itself. The limited availability of FDI data at any scale other than the national prevents the use of the most common utilised measure of foreign influence. Further the analysis in this paper is limited to a single year and much greater insight could be obtained if such data were collected on an on-going basis to allow the examination of changing patterns of foreign influence through time and how changes to entrepreneurial activities, behaviours and attitudes evolved through time. The results here therefore are a starting point, but as decision making moves from the regional to local level there is clearly a need for relevant information to be made available.

Overall this study has shown that it is too simplistic to view foreign influence in the local labour market as being positive or negative. Instead there are forces that weaken the 
existing local SME sector as well as ones that strengthen it. In preparation for future downturns to maximise the potential of this entrepreneurial talent developed due to foreign influence it is important that the correct infrastructure, institutions and resources are available to aid individuals' transfer from waged employment to business ownership.

\section{References}

Abreu, M. Grinevich, V. Kitson, M. and Savona, M. (2008), Absorptive Capacity and Regional Patterns of Innovation - DIUS-Research Report 08 11, London: Department for Innovation, Universities and Skills.

Acs, Z. J. Brooksbank, D. J. O'Gorman, C. Pickernell, D. G. and Terjesen, S. (2007a), “The knowledge spillover theory of entrepreneurship and foreign direct investment", Jena Economic Research Papers \#2007-059, Friedich-Schiller-University and Max Planck Institute of Economics, Jena.

Acs, Z. J. O'Gorman, C. Szerb, L. and Terjesen, S. (2007b), "Could the Irish miracle be repeated in Hungary?", Small Business Economics, Vol. 28 No. 2/3, pp. 123-142.

Aldrich, H. E. and Ruef, M. (2006), Organizations Evolving, Sage, London.

Almond, P. Ferner, A. and Tregaskis, O. (2015), "The changing context of regional governance of FDI in England", European Urban and Regional Studies, Vol. 22 No. 1, pp. 61-76.

Anderson, A. R. Osseichuk, E. and Illingworth, L. (2010), "Rural small businesses in turbulent times: impacts of the economic downturn", Entrepreneurship and Innovation, Vol. 11 No. 1, pp. 45-56. 
Audrestch, D. and Feldman, M. (1996), "R\&D spillovers and the geography of innovation and production", American Economic Review, Vol. 86 No. 3, pp. 630-640.

Audretsch, D. and Stephan, P. (1996), "Company-scientists locational links: the case of biotechnology", American Economic Review, Vol. 86 No. 3, pp. 641-652.

Audretsch, D.B. and Lehmann, E.E. (2005), "Does the knowledge spillover theory of entrepreneurship hold for regions?", Research Policy, Vol. 34 No. 8, pp. 1191-1202.

Baker, T. Gedajlovic, E. and Lubatkin, M. (2005), "A framework for comparing entrepreneurship processes across nations", Journal of International Business Studies, Vol. 36 No. 5, pp. 492-504.

Bandelj, N. (2008), From Communists to Foreign Capitalists: The Social Foundations of Foreign Direct Investment in Postsocialist Europe, Princeton University Press, Princeton, NJ.

Barbosa, N. and Eiriz, V. (2009), "The role of inward foreign direct investment on entrepreneurship", International Entrepreneurship and Management Journal, Vol. 5 No. 3, pp. 319-339.

Barrios, S. Görg, H. and Strobl, E. (2005), "Foreign direct investment, competition and industrial development in the host country", European Economic Review, Vol. 49 No. 7, pp. 1761-1784.

Bathelt, H. Malmberg, A. and Maskell, P. (2004), "Clusters and knowledge: local buzz, global pipelines, and the process of knowledge creation", Progress in Human Geography, Vol. 28 No. 1, pp. 31-56. 
Baum, J. A. C. and Silverman, B. S. (2004), "Picking winners or building them? Alliance, intellectual, and human capital as selection criteria in venturing financing and performance of biotechnology startups", Journal of Business Venturing, Vol. 17 No. 4, pp. 411-436.

Bellak, C. Leibrecht, M. and Riedl, A. (2008), "Labour costs and FDI flows into Central and Eastern European Countries: a survey of the literature and empirical evidence", Structural Change and Economic Dynamics, Vol. 19 No. 1, pp. 17-37.

Ben Hamida, L. and Gugler, P. (2009), "Are there demonstration-related spillovers from FDI? Evidence from Switzerland", International Business Review, Vol. 18 No. 5, 494-508.

Billington, N. (1999), "The location of foreign direct investment: an empirical analysis", Applied Economics, Vol. 31 No. 1, pp. 65-76.

Bishop, P. and Wiseman, N. (1999), "External ownership and innovation in the United Kingdom", Applied Economics, Vol. 31 No. 4, pp. 443-450.

Blalock, G. and Gertler, P. J. (2008), "Welfare gains from foreign direct investment through technology transfer to local suppliers", Journal of International Economics, Vol. 74 No. 2, pp. $402-421$

Blalock, G. and Simon, D. H. (2009), "Do all firms benefit equally from downstream FDI? The moderating effect of local suppliers' capabilities on productivity gains", Journal of International Business Studies, Vol. 40 No. 7, pp. 1095-1112.

Blanchflower, D. G. and Oswald, A. J. (1990), "Self-employment and the enterprise culture", British Social Attitudes, Vol. 7, pp. 127-143. 
Block, J. H. and Wagner, M. (2010), “Necessity and opportunity entrepreneurs in Germany: characteristics and earnings differentials", Schmalenbach Business Review, Vol. 62 No. 2, pp. 154-174.

Blomström, M. and Kokko, A. (2002), "FDI and human capital: a research agenda", Working Papers \#195, OECD, Paris, August.

Blonigen, B. A. Davies, R. B. Waddell, G. R. and Naughton, H. T. (2007), "FDI in space, spatial autoregressive relationships in foreign direct investment", European Economic Review, Vol. 51 No. 5, pp. 1303-1325.

Bradbury, K. L. (1994), "New England job changes during the recession: the role of selfemployment", New England Economic Review, September/October, pp. 45-57.

Buckley, P. J. Clegg, J. and Wang, C. (2007), "Is the relationship between inward FDI and spillover effects linear? An empirical examination of the case of China", Journal of International Business Studies, Vol. 38 No. 3, pp. 447-459.

Cantwell, J. (1989), Technological Innovation and Multinational Corporations, Blackwell, Oxford.

Carlsson, B. (2006), "The role of public policy in emerging clusters", in Braunerhjelm, P. and Feldman, M. P. (Eds.), Cluster Genesis: Technology-Based Industrial Development, Blackwell, Oxford, pp. 264-278.

Carree, M. van Stel, A. Thurik, R. and Wennekers, S. (2002), "Economic development and business ownership: an analysis using data of 23 OECD countries in the period 1976-1996", Small Business Economics, Vol. 19 No. 3, pp. 271-290. 
Caves, R. E. (1996), Multinational Enterprise and Economic Analysis, Cambridge University Press, New York, NY.

Christopherson, S. Michie, J. and Tyler, P. (2010), "Regional resilience: theoretical and empirical perspectives", Cambridge Journal of Regions, Economy and Society, Vol. 3 No. 1, pp. 3-10.

Cohen, J. Cohen, P. West, S. G. and Aiken, L. S. (2003) Applied multiple regression/correlation analysis for the behavioral sciences: third edition, Lawrence Erlbaum Associates, Mahwah, NJ.

Cohen, W. and Levinthal, L. (1990), “Absorptive capacity: a new perspective on learning and innovation", Administrative Science Quarterly, Vol. 35 No. 1, 128-152.

Collins, L. Hannon, P. D. and Smith, A. (2004), “Enacting entrepreneurial intent: the gaps between student needs and higher education capability", Education + Training, Vol. 46 No. (8/9), pp. 454-463.

Colombo, M. G. and Grilli, L. (2005), “Founders' human capital and the growth of new technology-based firms: a competence-based view", Research Policy, Vol. 34 No. 6, pp. 795-816.

Crone, M. (2002), "Local sourcing by multinational enterprise plants: evidence from the UK regions and the implications for policy", Environment and Planning C, Vol. 20 No. 1, pp. 131-149.

Crone, M. and Watts, H. D. (2000), "MNE supply linkages and the local SME sector: evidence from Yorkshire and Humberside", Local Economy, Vol. 15 No. 4, pp. 325-337. 
Crowe, J. (2011), “The Government's plans for decentralisation and localism: a progress report”, Political Quarterly, Vol. 82 No. 4, pp. 651-657.

Dahl, M. S. and Reichstein, T. (2007), "Are you experienced? Prior experience and the survival of new organizations", Industry and Innovation, Vol. 14 No. 5, pp. 497-511.

Davidsson, P. and Honig, B. (2003), "The role of social and human capital among nascent entrepreneurs", Journal of Business Venturing, Vol. 18 No. 3, pp. 301-331.

De Backer, K. and Sleuwaegen, L. (2003), "Does foreign direct investment crowd out domestic entrepreneurship", Review of Industrial Organization, Vol. 22 No. 1, pp. 67-84.

Decressin, J. and Fatás, A. (1995) 'Regional labor market dynamics in Europe”, European Economic Review, Vol. 39 No. 9, pp. 1627-1655.

Delgado, M. Porter, M. E. and Stern, S. (2010), "Clusters and entrepreneurship", Journal of Economic Geography, Vol. 10 No. 4, pp. 495-518.

Delmar, F. and Shane, S. (2006), "Does experience matter? The effect of founding team experience on the survival and sales of newly founded ventures", Strategic Organization, Vol. 4 No. 3, pp. 215-247.

Dimitropoulou, D. McCann, P. and Burke, S. P. (2013), "The determinants of the location of foreign direct investment in UK regions", Applied Economics, Vol. 45 No. 27, pp. 3853-3862.

Driffield, N. Love, J. H. and Menghinello, S. (2010), "The multinational enterprise as a source of international knowledge flows: direct evidence from Italy", Journal of International Business Studies, Vol. 41 No. 2, pp. 350-359. 
Dunning, J. H. (1992), Multinational Enterprise and the Global Economy, Addison Wesley, Wokingham.

Evans, D. S. and Leighton, L. S. (1989), "Some empirical aspects of entrepreneurship", American Economic Review, Vol. 79 No. 3, pp. 519-535.

Fallon, G. and Cook, M. (2014), "Explaining manufacturing and non-manufacturing inbound FDI location in five UK regions", Tijdschrift voor Economische en Sociale Geografie, Vol. 105 No. 3, pp. 331-348.

Feldman, M. P. Francis, J. and Bercovitz, J. (2005), "Creating a cluster while building a firm: entrepreneurs and the formation of industrial clusters", Regional Studies, Vol. 39 No. 1, pp. $129-141$.

Figlio, D. N. and Blonigen, B. A. (2000), "The effects of foreign direct investment on local communities", Journal of Urban Economics, Vol. 48 No. 2, pp. 338-363.

Florida, R. (2002), The Rise of the Creative Class, and How It's Transforming Work, Leisure, Community, and Everyday Life, Basic Books, New York, NY.

Florida, R. Mellander, C. and Stolarick, K. (2008), "Inside the black box of regional development - human capital, the creative class and tolerance", Journal of Economic Geography, Vol. 8 No. 5, pp. 615-649.

Foray, D. (2006), The Economics of Knowledge, MIT Press, Cambridge, MA.

Fotopoulos, G. (2014), "On the spatial stickiness of UK new firm formation rates", Journal of Economic Geography, Vol. 14 no. 3, pp. 651-679. 
Fu, X. (2008), "Foreign direct investment, absorptive capacity and regional innovation capabilities: evidence from China", Oxford Development Studies, Vol. 36 No. 1, pp. 89-110.

Fu, X. (2012), "Foreign direct investment and managerial knowledge spillovers through the diffusion of management practices", Journal of Management Studies, Vol. 49 No. 5, pp. 970-999.

Girma, S. and Wakelin, K. (2001), "Regional underdevelopment: is FDI the solution? A semi-parametric analysis", Internationalisation of Economic Policy Programme Research Paper Series \#2001/11, Leverhulm Centre for Research on Globalisation and Economic Policy, University of Nottingham, Nottingham.

Girma, S. Greenaway, D. and Wakelin, K. (2001), "Who benefits from foreign direct investment in the UK?", Scottish Journal of Political Economy, Vol. 48 No. 2, pp. 119-133.

Görg, H. and Strobl, E. (2001), "Multination companies and productivity spillovers: a metaanalysis", Economic Journal, Vol. 111 No. 475, pp. F723-F739.

Görg, H. and Strobl, E. (2003), “'Footloose' multinationals”, Manchester School, Vol. 71 No. 1, pp. 1-19.

Görg, H. and Strobl, E. (2005), "Foreign direct investment and local economic development: beyond productivity spillovers", in Moran, T. H. Graham, E. M. and Blomström, M. (Eds.), Does Foreign Direct Investment Promote Development, Institute for International Economics, Washington, DC, pp. 137-157.

Grossman, G. M. (1984), "International trade, foreign investment, and the formation of the entrepreneurial class", American Economic Review, Vol. 74 No. 4, pp. 605-614. 
Gu, S. and Lundvall, B. A. (2006), "China's innovation system and the move toward harmonious growth and endogenous innovation", Innovation: Management, Policy and Practice, Vol. 8 No. 1, pp. 1-26.

Hanson, G. H. (2001), "Should countries promote foreign direct investment?", G-24 Discussion Paper Series \#9, United Nations, New York and Geneva, February.

Harding, R. (2007), GEM UK 2006, London Business School, London.

Haskel, J. E. Pereira, S. C. and Slaughter, M. J. (2007), "Does inward foreign direct investment boost the productivity of domestic firms?", Review of Economics and Statistics, Vol. 89 No. 3, pp. 482-496.

Hill, S. and Munday, M. (1991), "The UK regional distribution of Foreign Direct Investment: analysis and determinants", Regional Studies, Vol. 26 No. 6, pp. 535-544.

HM Government (2010a), Decentralisation and the Localism Bill: an essential guide, London: Department for Communities and Local Government, London.

HM Government (2010b), Local growth: realising every place's potential, HM Stationery Office, London.

Hu, A. G. (2007), "Technology parks and regional economic growth in China", Research Policy, Vol. 36 No. 1, 76-87.

Hudson, R. (2010), "Resilient regions in an uncertain world: wishful thinking or a practical reality?", Cambridge Journal of Regions, Economy and Society, Vol. 3 No. 1, pp. 11-25. 
Huggins, R. Lou, S. and Thompson, P. (2014), "The competitiveness of China's leading regions: benchmarking their knowledge-based economies", Tijdschrift voor economische en sociale geografie, Vol. 105 No. 3, pp. 241-267.

Javorcik, B. S. (2004), "Does foreign direct investment increase the productivity of domestic firms? In search of spillovers through backward linkages", American Economic Review, Vol. 94 No. 3, pp. 605-627.

Keller, W. and Yeaple, S. R. (2009), "Multinational enterprises, international trade, and productivity growth: firm-level evidence from the United States", Review of Economics and Statistics, Vol. 91 No. 4, pp. 821-831.

Kihlstrom, R. and Laffont, J. J. (1979), "A general equilibrium entrepreneurial theory of the firm formation based on risk aversion", Journal of Political Economy, Vol. 87 No. 4, pp. 719748.

Kim, G. (2007), "The analysis of self-employment levels over the life-cycle", Quarterly Review of Economics and Finance, Vol. 47 No. 3, pp. 397-410.

Kim, P. H. and Li, M. (2014), "Injecting demand through spillovers: foreign direct investment, domestic socio-political conditions, and host-country entrepreneurial activity", Journal of Business Venturing, Vol. 29 No. 2, pp. 210-231.

Lévesque, M. and Minniti, M. (2006), "The effect of aging on entrepreneurial behaviour", Journal of Business Venturing, Vol. 21 No. 2, pp. 177-194. 
Liu, X. Siler, P. Wang, C. and Wei, Y. (2000), "Productivity spillovers from foreign direct investment, evidence from UK industry level panel data", Journal of International Business Studies, Vol 31 No. 3, pp. 407-425.

Lucas Jr., R. E. (1978), "On the size distribution of business firms", Bell Journal of Economics, Vol. 9 No. 2, pp. 508-523.

Lyon, F. Bertotti, M. Evans, M. Smallbone, D. Potts, G. and Ramsden, P. (2002), Measuring enterprise impacts in deprived areas: Report to the Small Business Service, Centre for Enterprise and Economic Development Research (CEEDR), London.

Mahroum, S. Huggins, R. Clayton, N. Pain. K. and Taylor, P. (2008), Innovation by Adoption: Measuring and Mapping Absorptive Capacity in UK Nations and Regions, London: NESTA.

Markusen, J. R. and Venables, A. J. (1999), "Foreign direct investment as a catalyst for industrial development", European Economic Review, Vol. 43 No. 2, pp. 335-356.

Martin, R. (2012), "Regional economic resilience, hysteresis and recessionary shocks", Journal of Economic Geography, Vol. 12 No. 1, pp. 1-32.

Martins, P. (2011), "Paying more to hire the best? Foreign firms, wages and worker mobility", Economic Inquiry, Vol. 49 No. 2, pp. 349-363.

Maskell, P. and Malmberg, A. (1999), "Localised learning and industrial competitiveness", Cambridge Journal of Economics, Vol. 23 No. 1, pp. 167-186.

McCormick, B. (1997), "Regional unemployment and labour mobility in the UK", European Economic Review, Vol. 41 No. 3-5, 581-589. 
Meyer, K. E. (2004), "Perspectives on multinational enterprises in emerging economies", Journal of International Business Studies, Vol. 35 No. 4, pp. 259-276.

Meyer, K. E. and Sinani, E. (2009), "When and where does foreign direct investment generate positive spillovers? A meta-analysis", Journal of International Business Studies, Vol. 40 No. 7, 1075-1094.

Moy, J. W. and Lee, S. M. (2002), "The career choice of business graduates: SMEs or MNCs?", Career Development International, Vol. 7 No. 6, pp. 339-347.

Mueller, P. (2006), "Entrepreneurship in the region: breeding ground for nascent entrepreneurs", Small Business Economics, Vol. 27 No. 1, pp. 41-58.

Munday, M. Roberts, A. and Roche, N. (2009), A review of the economic evidence on the determinants and effects of foreign direct investment, Welsh Economy Research Unit, Cardiff University, Cardiff.

Office for National Statistics (2010), Foreign Ownership of Businesses in the United Kingdom, Office for National Statistics, London.

Oi, W. Y. (1983), "Heterogeneous firms and the organisation of production", Economic Inquiry, Vol. 21 No. 2, pp. 147-171.

O'Malley, E. and O'Gorman, C. (2001), "Competitive advantage in the Irish indigenous software industry and the role of inward foreign direct investment", European Planning Studies, Vol. 9 No. 3, pp. 303-321. 
Pandit, N. R. Cook, G. A. S. and Swann, G. M. P. (2002), "The dynamics of industrial clustering in British financial services", Service Industries Journal, Vol. 21 No. 4, 33-61.

Phelps, N. A. (1993), "Branch plants and the evolving spatial division of labour: a study of material linkage change in the Northern region of England", Regional Studies, Vol. 27 No. 2, pp. 87-101.

Phelps, N. A. Mackinnon, D. Stone, I. and Braidford, P. (2003), "Embedding the multinationals? Institutions and the development of overseas manufacturing affiliates in Wales and North East England", Regional Studies, Vol. 37 No. 1, pp. 27-40.

Pike, A. Dawley, S. and Tomaney, J. (2010), "Resilience, adaptation and adaptability", Cambridge Journal of Regions, Economy and Society, Vol. 3 No. 1, pp. 59-70.

Pitelis, C. N. and Teece, D. J. (2010), "Cross-border market co-creation, dynamic capabilities and the entrepreneurial theory of the multinational enterprise", Industrial and Corporate Change, Vol. 19 No. 4, pp. 1247-1270.

Plunkett, J. and Pessoa, J. P. (2013), A Polarising Crisis? The changing shape of the UK and US labour markets from 2008 to 2012, Resolution Foundation, London.

Pugalis, L. and Bentley, G. (2013), "Storming or performing? Local Enterprise Partnerships two years on", Local Economy, Vol. 28 No. 7/8, pp. 863-874.

Rae, D. Price, L. Bosworth, G. and Parkinson, P. (2012), "Business inspiration: small business leadership in recovery?", Industry and Higher Education, Vol. 26 No. 6, pp. 473489. 
Robinson, P. B. and Sexton, E. A. (1994), "The effect of education and experience on selfemployment success", Journal of Business Venturing, Vol. 9 No. 2, 141-156.

Rodríguez-Clare, A. (1996), “Multinational, linkages, and economic development”, American Economic Review, Vol. 86 No. 4, pp. 852-873.

Roper, S. and Love, J. H. (2006), "Innovation and regional absorptive capacity: the labour market dimension", Annals of Regional Science, Vol. 40 No. 2, pp. 437-447.

Rossiter, W. and Price, L. (2013), "Local economic strategy development under Regional Development agencies and Local Enterprise Partnerships: applying the lens of the multiple streams framework", Local Economy, Vol. 28 No. 7/8, pp. 852-862.

Simmie, J. and Martin, R. (2010), "The economic resilience of regions: towards an evolutionary approach", Cambridge Journal of Regions, Economy and Society, Vol. 3 No. 1, pp. 27-43.

Song, J. Almeida, P. and Wu, G. (2003), "Learning-by-hiring: when is mobility more likely to facilitate interfirm knowledge transfer?", Management Science, Vol. 49 No. 4, pp. 351-365.

Spencer, J. W. (2008), "The impact of multinational enterprise strategy on indigenous enterprises: horizontal spillovers and crowding out in developing countries", Academy of Management Review, Vol. 33 No. 2, pp. 341-361.

Stathopoulou, S. Psaltopoulos, D. and Skuras, D. (2004), "Rural entrepreneurship in Europe: a research framework and agenda", International Journal of Entrepreneurial Behaviour and Research, Vol. 10 No. 6, pp. 404-426. 
Stone, I. and Peck, F. (1996), "The foreign-owned manufacturing sector in UK peripheral regions, 1978-1993: restructuring and comparative performance", Regional Studies, Vol. 30 No. 1 , pp. 55-68.

Storey, D. J. (1982), Entrepreneurship and the New Firm, Croom Helm, London.

Storey, D. J. (1994), Understanding the Small Business Sector, Routledge, London.

Storey, D. J. and Johnson, S. (1987), "Regional variations in entrepreneurship in the UK", Scottish Journal of Political Economy, Vol. 34 No. 3, pp. 161-173.

Taylor, M. P. (1996), "Earnings, independence or unemployment: why become selfemployed?", Oxford Bulletin of Economics and Statistics, Vol. 58 No. 2, pp. 253-266.

Ucbasaran, D. Westhead, P. and Wright, M. (2008), "Opportunity identification and pursuit: does an entrepreneur's human capital matter?", Small Business Economics, Vol. 30 No. 2, pp. 153-173.

Van der Sluis, J. and van Praag, M. (2008), "Education and entrepreneurship selection and performance: a review of the empirical literature", Journal of Economic Surveys, Vol. 22 No. $5,795-841$

Vernon, R. (1960), Metropolis 1985: Interpretation of the findings of the New York metropolitan region study, Harvard University Press, Cambridge, MA.

Wren, C. and Jones, J. (2011), "Assessing the regional impact of grants on FDI location: evidence from UK regional policy, 1985-2005", Journal of Regional Science, Vol. 51 No. 3, 497-517. 
Zaheer, S. (1995), "Overcoming the liabilities of foreignness", Academy of Management Journal, Vol. 38 No. 2, pp. 341-363.

PLEASE INSERT TABLE A1 ABOUT HERE

PLEASE INSERT TABLE A2 ABOUT HERE 
Table 1: Foreign Ownership and Entrepreneurship Index

\begin{tabular}{|c|c|c|c|c|}
\hline $\begin{array}{l}\text { Entrepreneurship } \\
\text { Index Rank }\end{array}$ & $\begin{array}{l}\text { Entrepreneurship } \\
\text { Index }\end{array}$ & Locality & Region & Foreign Influence \\
\hline 1 & 353.4 & Chiltern & South East & 12.2 \\
\hline 2 & 340.8 & South Bucks & South East & 18.2 \\
\hline 3 & 333.2 & Rushcliffe & East Midlands & 7.6 \\
\hline 4 & 329.8 & Hart & South East & 22.9 \\
\hline 5 & 329.3 & Mole Valley & South East & 19.0 \\
\hline 6 & 328.4 & Tandridge & South East & 11.1 \\
\hline 7 & 328.0 & Richmond upon Thames & London & 10.3 \\
\hline 8 & 319.0 & Horsham & South East & 12.5 \\
\hline 9 & 314.3 & Bromsgrove & West Midlands & 8.3 \\
\hline 10 & 314.3 & East Dorset & South West & 6.0 \\
\hline 368 & 65.5 & Bolsover & East Midlands & 13.6 \\
\hline 369 & 64.7 & North Lanarkshire & Scotland & 16.0 \\
\hline 370 & 63.8 & Lincoln & East Midlands & 14.2 \\
\hline 371 & 63.1 & Salford & North West & 10.7 \\
\hline 372 & 58.6 & Halton & North West & 25.2 \\
\hline 373 & 57.7 & Leicester & East Midlands & 9.4 \\
\hline 374 & 54.1 & Corby & East Midlands & 23.7 \\
\hline 375 & 52.9 & Sandwell & West Midlands & 14.9 \\
\hline 376 & 51.5 & Peterborough & East of England & 19.0 \\
\hline 377 & 43.6 & Kingston upon Hull, City of & $\begin{array}{l}\text { Yorkshire and } \\
\text { Humber }\end{array}$ & 10.2 \\
\hline $\begin{array}{l}\text { Spearman Rank } \\
\text { Correlation } \\
\text { Entrepreneurship } \\
\text { Index and Foreign } \\
\text { Influence }\end{array}$ & $\begin{array}{c}-0.240 \\
(0.000)\end{array}$ & & & \\
\hline
\end{tabular}


Table 2: Pearson correlation coefficients of entrepreneurship measures with local labour market, infrastructure and economic conditions variables

\begin{tabular}{lcc} 
& SMEs & Firm Births \\
\hline Foreign Influence & -0.557 & $\mathbf{0 . 3 8 0}$ \\
& $(0.000)$ & $(0.000)$ \\
Population Density & -0.332 & $\mathbf{. 6 9 5}$ \\
& $(0.000)$ & $(0.000)$ \\
Prime Age Population & -0.170 & $\mathbf{0 . 5 3 4}$ \\
& $(0.001)$ & $(0.000)$ \\
Rail Connections & -0.209 & $\mathbf{0 . 4 1 7}$ \\
& $(0.000)$ & $(0.000)$ \\
Proximity to Major Airport & -0.228 & 0.436 \\
& $(0.000)$ & $(0.000)$ \\
Proximity to Primary Maritime Port & -0.046 & $\mathbf{0 . 3 0 4}$ \\
& $(0.377)$ & $(0.000)$ \\
Median Wages & 0.000 & $\mathbf{0 . 3 3 7}$ \\
& $(0.996)$ & $(0.000)$ \\
Unemployment Change & -0.316 & $\mathbf{0 . 3 1 9}$ \\
& $(0.000)$ & $(0.000)$ \\
Employment in Financial Services & -0.122 & $\mathbf{0 . 4 4 1}$ \\
& $(0.018)$ & $(0.000)$ \\
Employment in Manufacturing & -0.014 & $-\mathbf{0 . 3 2 2}$ \\
Managerial, Professional, Associate & $(0.786)$ & $(0.000)$ \\
Professional Positions & 0.013 & $\mathbf{0 . 2 1 4}$ \\
Proportion with NVQ Level 4+ Qualifications & $(0.807)$ & $(0.000)$ \\
& 0.029 & $\mathbf{0 . 1 4 6}$ \\
& $(0.575)$ & $(0.005)$ \\
\hline
\end{tabular}

Notes: p-values in parenthesis; emboldened values significant at the $5 \%$ level 
Table 3 - Regressions of Size of SME Sector

\begin{tabular}{|c|c|c|c|}
\hline & Model A1 & Model A2 & Model A3 \\
\hline Foreign Influence & $\begin{array}{c}-0.0211 \\
(0.000)\end{array}$ & $\begin{array}{r}-0.0210 \\
(0.000)\end{array}$ & $\begin{array}{c}-0.0204 \\
(0.000)\end{array}$ \\
\hline Foreign Influence ${ }^{2}$ & $\begin{array}{l}0.0000 \\
(0.813)\end{array}$ & $\begin{array}{l}-0.0001 \\
(0.438)\end{array}$ & $\begin{array}{l}-0.0003 \\
(0.097)\end{array}$ \\
\hline Proportion with NVQ Level 4+ Qualifications & $\begin{array}{l}-0.0050 \\
(0.003)\end{array}$ & & \\
\hline $\begin{array}{l}\text { Foreign Influence * Proportion with NVQ Level } \\
\text { 4+ Qualifications }\end{array}$ & $\begin{array}{l}-0.0003 \\
(0.186)\end{array}$ & & \\
\hline $\begin{array}{l}\text { Foreign Influence }{ }^{2} \text { * Proportion with NVQ Level } \\
\text { 4+ Qualifications }\end{array}$ & $\begin{array}{l}\mathbf{0 . 0 0 0 1} \\
(0.004)\end{array}$ & & \\
\hline $\begin{array}{l}\text { Managerial, Professional, Associate } \\
\text { Professional Positions }\end{array}$ & & $\begin{array}{r}-0.0049 \\
(0.009)\end{array}$ & \\
\hline $\begin{array}{l}\text { Foreign Influence * Managerial, Professional, } \\
\text { Associate Professional Positions }\end{array}$ & & $\begin{array}{l}-0.0001 \\
(0.823)\end{array}$ & \\
\hline $\begin{array}{l}\text { Foreign Influence }{ }^{2} \text { * Managerial, Professional, } \\
\text { Associate Professional Positions }\end{array}$ & & $\begin{array}{l}0.0000 \\
(0.123)\end{array}$ & \\
\hline Employment in Financial Services & & & $\begin{array}{l}-0.0030 \\
(0.312)\end{array}$ \\
\hline Employment in Manufacturing & & & $\begin{array}{l}0.0007 \\
(0.805)\end{array}$ \\
\hline $\begin{array}{l}\text { Foreign Influence * Employment in Financial } \\
\text { Services }\end{array}$ & & & $\begin{array}{l}0.0004 \\
(0.251)\end{array}$ \\
\hline $\begin{array}{l}\text { Foreign Influence * Employment in } \\
\text { Manufacturing }\end{array}$ & & & $\begin{array}{l}\mathbf{0 . 0 0 1 0} \\
(0.026)\end{array}$ \\
\hline $\begin{array}{l}\text { Foreign Influence }{ }^{2} \text { * Employment in Financial } \\
\text { Services }\end{array}$ & & & $\begin{array}{l}0.0000 \\
(0.274)\end{array}$ \\
\hline $\begin{array}{l}\text { Foreign Influence }{ }^{2 *} \text { Employment in } \\
\text { Manufacturing }\end{array}$ & & & $\begin{array}{l}0.0000 \\
(0.998)\end{array}$ \\
\hline Population Density & $\begin{array}{r}-0.0027 \\
(0.000)\end{array}$ & $\begin{array}{l}-0.0026 \\
(0.000)\end{array}$ & $\begin{array}{l}-0.0025 \\
(0.000)\end{array}$ \\
\hline Prime Age Population & $\begin{array}{l}\mathbf{0 . 0 2 4 1} \\
(0.007)\end{array}$ & $\begin{array}{l}\mathbf{0 . 0 2 7 0} \\
(0.003)\end{array}$ & $\begin{array}{l}\mathbf{0 . 0 2 7 0} \\
(0.003)\end{array}$ \\
\hline Rail Connections & $\begin{array}{c}-0.0004 \\
(0.113)\end{array}$ & $\begin{array}{c}-0.0004 \\
(0.057)\end{array}$ & $\begin{array}{c}-0.0005 \\
(0.022)\end{array}$ \\
\hline Proximity to Major Airport & $\begin{array}{l}-0.0255 \\
(0.212)\end{array}$ & $\begin{array}{c}-0.0239 \\
(0.246)\end{array}$ & $\begin{array}{c}-0.0279 \\
(0.178)\end{array}$ \\
\hline Proximity to Primary Maritime Port & $\begin{array}{l}0.0033 \\
(0.863)\end{array}$ & $\begin{array}{l}0.0001 \\
(0.994)\end{array}$ & $\begin{array}{l}0.0092 \\
(0.644)\end{array}$ \\
\hline Median Wages & $\begin{array}{l}\mathbf{0 . 0 0 5 0} \\
(0.010)\end{array}$ & $\begin{array}{l}\mathbf{0 . 0 0 5 7} \\
(0.007)\end{array}$ & $\begin{array}{l}\mathbf{0 . 0 0 4 5} \\
(0.031)\end{array}$ \\
\hline Unemployment Change & $\begin{array}{c}-0.0108 \\
(0.000)\end{array}$ & $\begin{array}{l}-0.0111 \\
(0.000)\end{array}$ & $\begin{array}{c}-0.0091 \\
(0.001)\end{array}$ \\
\hline
\end{tabular}

Notes: p-values in parenthesis; emboldened values significant at the $5 \%$ level 
Table 3: Continued

\begin{tabular}{lccc}
\hline & Model A1 & Model A2 & Model A3 \\
\hline Constant & $\begin{array}{c}99.6159 \\
(0.000)\end{array}$ & $\begin{array}{c}\mathbf{9 9 . 6 2 0 0} \\
(0.000)\end{array}$ & $\begin{array}{c}\mathbf{9 9 . 6 1 4 1} \\
(0.000)\end{array}$ \\
$N$ & & & 377 \\
$R^{2}$ & 377 & 377 & \\
& & & 0.457 \\
F-test & 0.461 & 0.454 & \\
& & & 20.245 \\
& 25.936 & 25.261 & $(0.000)$ \\
F-test & $(0.000)$ & $(0.000)$ & \\
Change in R2 Interaction Terms & & & 2.307 \\
\hline N & 4.178 & 1.630 & $(0.058)$ \\
\hline
\end{tabular}

Notes: p-values in parenthesis; emboldened values significant at the $5 \%$ level 
Table 4 - Regressions of Firm Births

\begin{tabular}{|c|c|c|c|}
\hline & Model B1 & Model B2 & Model B3 \\
\hline Foreign Influence & $\begin{array}{l}0.1109 \\
(0.000)\end{array}$ & $\begin{array}{l}\mathbf{0 . 1 0 8 1} \\
(0.000)\end{array}$ & $\begin{array}{l}\mathbf{0 . 1 2 7 3} \\
(0.000)\end{array}$ \\
\hline Foreign Influence ${ }^{2}$ & $\begin{array}{l}-0.0031 \\
(0.129)\end{array}$ & $\begin{array}{l}-0.0025 \\
(0.215)\end{array}$ & $\begin{array}{l}-0.0010 \\
(0.631)\end{array}$ \\
\hline Proportion with NVQ Level 4+ Qualifications & $\begin{array}{l}-0.0312 \\
(0.108)\end{array}$ & & \\
\hline $\begin{array}{l}\text { Foreign Influence * Proportion with NVQ Level } \\
\text { 4+ Qualifications }\end{array}$ & $\begin{array}{l}-0.0075 \\
(0.010)\end{array}$ & & \\
\hline $\begin{array}{l}\text { Foreign Influence }{ }^{2 *} \text { Proportion with NVQ Level } \\
\text { 4+ Qualifications }\end{array}$ & $\begin{array}{l}0.0003 \\
(0.375)\end{array}$ & & \\
\hline $\begin{array}{l}\text { Managerial, Professional, Associate } \\
\text { Professional Positions }\end{array}$ & & $\begin{array}{l}-0.0411 \\
(0.058)\end{array}$ & \\
\hline $\begin{array}{l}\text { Managerial, Professional, Associate } \\
\text { Professional Positions }\end{array}$ & & $\begin{array}{l}-0.0411 \\
(0.058)\end{array}$ & \\
\hline $\begin{array}{l}\text { Foreign Influence }{ }^{2} \text { * Managerial, Professional, } \\
\text { Associate Professional Positions }\end{array}$ & & $\begin{array}{l}\mathbf{0 . 0 0 0 7} \\
(0.007)\end{array}$ & \\
\hline Employment in Financial Services & & & $\begin{array}{l}-0.0601 \\
(0.070)\end{array}$ \\
\hline Employment in Manufacturing & & & $\begin{array}{l}-0.1255 \\
(0.000)\end{array}$ \\
\hline $\begin{array}{l}\text { Foreign Influence * Employment in Financial } \\
\text { Services }\end{array}$ & & & $\begin{array}{l}-0.0228 \\
(0.000)\end{array}$ \\
\hline $\begin{array}{l}\text { Foreign Influence * Employment in } \\
\text { Manufacturing }\end{array}$ & & & $\begin{array}{l}-0.0162 \\
(0.002)\end{array}$ \\
\hline $\begin{array}{l}\text { Foreign Influence }{ }^{2} \text { * Employment in Financial } \\
\text { Services }\end{array}$ & & & $\begin{array}{l}\mathbf{0 . 0 0 0 8} \\
(0.016)\end{array}$ \\
\hline $\begin{array}{l}\text { Foreign Influence }{ }^{2} \text { * Employment in } \\
\text { Manufacturing }\end{array}$ & & & $\begin{array}{l}0.0003 \\
(0.442)\end{array}$ \\
\hline Population Density & $\begin{array}{l}\mathbf{0 . 0 8 1 8} \\
(0.000)\end{array}$ & $\begin{array}{l}\mathbf{0 . 0 8 1 2} \\
(0.000)\end{array}$ & $\begin{array}{l}\mathbf{0 . 0 7 6 8} \\
(0.000)\end{array}$ \\
\hline Prime Age Population & $\begin{array}{l}0.3925 \\
(0.000)\end{array}$ & $\begin{array}{l}\mathbf{0 . 3 6 3 7} \\
(0.000)\end{array}$ & $\begin{array}{l}\mathbf{0 . 4 3 2 9} \\
(0.000)\end{array}$ \\
\hline Rail Connections & $\begin{array}{c}-0.0038 \\
(0.159)\end{array}$ & $\begin{array}{c}-0.0031 \\
(0.242)\end{array}$ & $\begin{array}{c}-0.0039 \\
(0.138)\end{array}$ \\
\hline Proximity to Major Airport & $\begin{array}{l}\mathbf{0 . 7 4 0 2} \\
(0.002)\end{array}$ & $\begin{array}{l}\mathbf{0 . 7 1 4 5} \\
(0.003)\end{array}$ & $\begin{array}{l}\mathbf{0 . 7 1 3 0} \\
(0.002)\end{array}$ \\
\hline Proximity to Primary Maritime Port & $\begin{array}{l}1.4145 \\
(0.000)\end{array}$ & $\begin{array}{l}1.3399 \\
(0.000)\end{array}$ & $\begin{array}{l}1.1087 \\
(0.000)\end{array}$ \\
\hline Median Wages & $\begin{array}{l}\mathbf{0 . 0 6 9 7} \\
(0.002)\end{array}$ & $\begin{array}{l}\mathbf{0 . 0 7 3 9} \\
(0.002)\end{array}$ & $\begin{array}{l}0.0295 \\
(0.204)\end{array}$ \\
\hline Unemployment Change & $\begin{array}{l}0.2100 \\
(0.000)\end{array}$ & $\begin{array}{l}\mathbf{0 . 1 9 7 0} \\
(0.000)\end{array}$ & $\begin{array}{l}\mathbf{0 . 1 9 7 2} \\
(0.000)\end{array}$ \\
\hline
\end{tabular}

Notes: p-values in parenthesis; emboldened values significant at the $5 \%$ level 
Table 4: Continued

\begin{tabular}{|c|c|c|c|}
\hline & Model B1 & Model B2 & Model B3 \\
\hline Constant & $\begin{array}{c}11.0923 \\
(0.000)\end{array}$ & $\begin{array}{l}11.1708 \\
(0.000)\end{array}$ & $\begin{array}{c}11.4229 \\
(0.000)\end{array}$ \\
\hline$N$ & 377 & 377 & 377 \\
\hline$R^{2}$ & 0.697 & 0.707 & 0.725 \\
\hline F-test & $\begin{array}{l}69.860 \\
(0.000)\end{array}$ & $\begin{array}{l}73.047 \\
(0.000)\end{array}$ & $\begin{array}{l}63.574 \\
(0.000)\end{array}$ \\
\hline $\begin{array}{l}\text { F-test } \\
\text { Change in R2 Interaction Terms }\end{array}$ & $\begin{array}{l}3.450 \\
(0.033)\end{array}$ & $\begin{array}{l}9.563 \\
(0.000)\end{array}$ & $\begin{array}{l}7.789 \\
(0.000)\end{array}$ \\
\hline
\end{tabular}

Notes: p-values in parenthesis; emboldened values significant at the $5 \%$ level 
Table A1: Description of Variables and Data Sources

\begin{tabular}{|c|c|c|c|c|}
\hline Variable & Description & Scale & Source & Date \\
\hline SMES & $\begin{array}{c}\text { Firms employing less that } 250 \text { full time } \\
\text { equivalent staff }\end{array}$ & $\begin{array}{l}\text { Proportion of all firms in the } \\
\text { locality }\end{array}$ & $\begin{array}{l}\text { ONS UK Business: Activity, } \\
\text { Size and Location }\end{array}$ & 2011 \\
\hline Firm Births & New firms registered & $\begin{array}{l}\text { Scaled by stock of firms at } \\
\text { the beginning of } 2011\end{array}$ & ONS Business Demography & 2011 \\
\hline Foreign Influence & Employment in foreign owned firms & $\begin{array}{l}\text { Proportion of all local } \\
\text { employment }\end{array}$ & $\begin{array}{l}\text { ONS Foreign Ownership of } \\
\text { Businesses in the United } \\
\text { Kingdom Analysis }\end{array}$ & 2010 \\
\hline Population Density & Residents in local area & Population per hectare & Mid-year Population Estimates & 2010 \\
\hline Prime Age Population & $\begin{array}{c}\text { Population aged between } 35 \text { and } 44 \\
\text { years }\end{array}$ & Proportion of population & Mid-year Population Estimates & 2010 \\
\hline Rail Connections & $\begin{array}{c}\text { Gross rail journeys per day (in and out } \\
\text { of local stations) }\end{array}$ & Per head of population & $\begin{array}{c}\text { Department of Transport/Office } \\
\text { of Rail Regulation }\end{array}$ & 2010 \\
\hline Proximity to Major Airport & $\begin{array}{l}\text { Within } 25 \text { miles of an airport serving at } \\
\text { least } 4 \text { million passengers per year }\end{array}$ & Dummy variable & Department for Transport & 2008 \\
\hline $\begin{array}{c}\text { Proximity to Primary Maritime } \\
\text { Port }\end{array}$ & $\begin{array}{c}\text { Within } 25 \text { miles of a primary maritime } \\
\text { port (1 million passengers or } 25 \text { million } \\
\text { tonnes of freight) }\end{array}$ & Dummy variable & Department for Transport & 2002 \\
\hline Median Wages & $\begin{array}{l}\text { Median wage including overtime } \\
\text { payments }\end{array}$ & Pounds Sterling & $\begin{array}{l}\text { Annual Survey of Hours and } \\
\text { Earnings }\end{array}$ & 2010 \\
\hline Unemployment Change & $\begin{array}{l}\text { Proportion of population claiming job } \\
\text { seekers allowance }\end{array}$ & $\begin{array}{l}\text { Change on average rate for } \\
\text { preceding five years (2005- } \\
\text { 2009) }\end{array}$ & Claimant Count NOMIS & 2010 \\
\hline $\begin{array}{l}\text { Employment in Financial } \\
\text { Services }\end{array}$ & $\begin{array}{c}\text { Standard Industrial Classification (2007) } \\
\mathrm{K} \text { to N }\end{array}$ & Proportion in employment & Annual Population Survey & 2010 \\
\hline Employment in Manufacturing & $\begin{array}{c}\text { Standard Industrial Classification (2007) } \\
\text { C }\end{array}$ & Proportion in employment & Annual Population Survey & 2010 \\
\hline $\begin{array}{l}\text { Managerial, Professional, } \\
\text { Associate Professional Positions }\end{array}$ & $\begin{array}{l}\text { Standard Occupation Classification } \\
\text { (2010) 1, } 2 \text { and } 3\end{array}$ & Proportion in employment & Annual Population Survey & 2010 \\
\hline $\begin{array}{c}\text { Proportion with NVQ Level 4+ } \\
\text { Qualifications }\end{array}$ & $\begin{array}{l}\text { Population holding university level } \\
\text { qualifications or equivalent }\end{array}$ & Proportion of population & Annual Population Survey & 2010 \\
\hline
\end{tabular}


Table A2: Variables used in Entrepreneurship Index

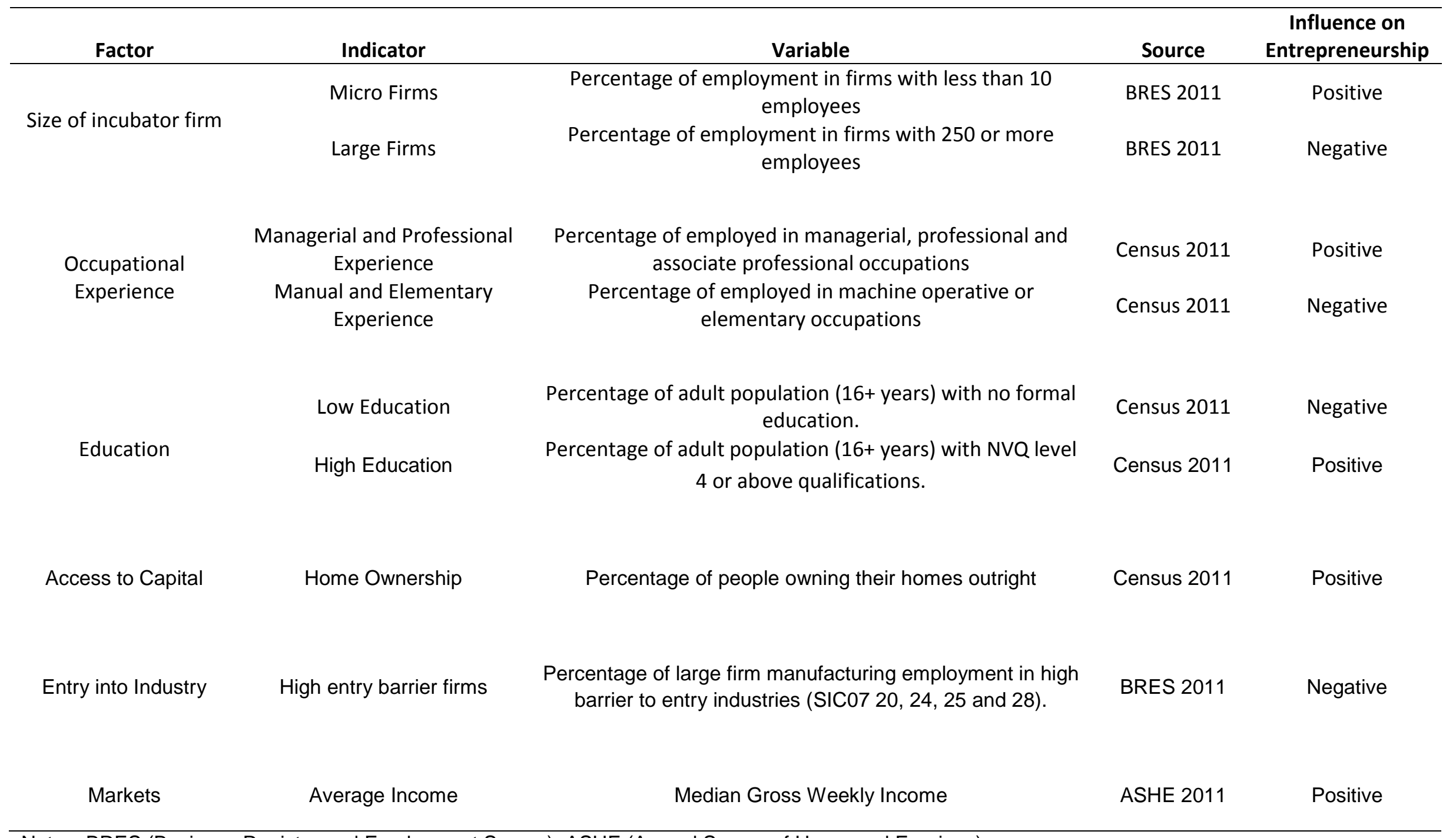

Notes: BRES (Business Register and Employment Survey); ASHE (Annual Survey of Hours and Earnings) 